\title{
Snuffing Out the Moon: Kino/Bio Politics, Movement and the State of Exception
}

David Waterman

\section{OpenEdition}

1 Journals

Electronic version

URL: http://journals.openedition.org/ces/4048

DOI: $10.4000 /$ ces.4048

ISSN: 2534-6695

Publisher

SEPC (Société d'études des pays du Commonwealth)

\section{Electronic reference}

David Waterman, «Snuffing Out the Moon: Kino/Bio Politics, Movement and the State of Exception », Commonwealth Essays and Studies [Online], 43.1 | 2020, Online since 30 October 2020, connection on 09 November 2020. URL : http://journals.openedition.org/ces/4048 ; DOI : https://doi.org/10.4000/ ces. 4048

This text was automatically generated on 9 November 2020.

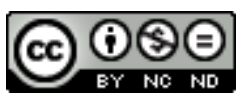

Commonwealth Essays and Studies is licensed under a Licence Creative Commons Attribution - Pas d'Utilisation Commerciale - Pas de Modification 4.0 International. 


\title{
Snuffing Out the Moon: Kino/Bio Politics, Movement and the State of Exception
}

\author{
David Waterman
}

1 Osama Siddique's debut novel, Snuffing Out the Moon (2017), is (to paraphrase Mohsin Hamid in Exit West, 209) a migration through time. Like the Buddha "travelling through multiple lives on the road" (Siddique 2017, 18), the novel is set across four millennia in the Indus Valley, moving between eventful periods in this region's history: 2084 BCE (The Land of the Indus), 455 CE (The Land of the Buddha), 1620 (The Land of the Mughal), 1857 (The Land of the Sahib), 2009 (The Land of the Wakeel), and finally 2084 (The Land of Tomorrow). Shifting between these six different historical eras in South Asia, Siddique - deploying literary genres from folktale to historical fiction to sci-fi charts a politics of movement, or "kinopolitics," as defined by Thomas Nail, who has become an influential philosopher by placing the movement that defines the migrant at the center of the history of political power:

Kinopolitics is the politics of movement, from the Greek word kino, meaning movement. If we are going to take the figure of the migrant seriously as a constitutive, and not derivative, figure of Western politics, we have to change the starting point of political theory. Instead of starting with a set of preexisting citizens, kinopolitics begins with the flows of migrants and the ways they have circulated or sedimented into citizens and states-as well as emphasizing how migrants have constituted a counter-power and alternative to state structures. In short, kinopolitics is the reinvention of political theory from the primacy of social motion instead of the state. (Nail and Settle 2016)

Migration is never innocent of political motivations and repercussions; as Nail insists, "the migrant is the political figure of movement" $(2015,11)$. Mohenjodaro, a beautiful model city, is now falling into ruin because of decadence and a caste of priests who have usurped religion from the people and turned it into a political weapon, a neartotalitarian situation which, accompanied by natural catastrophes, forces exodus. The "Land of Tomorrow" - the fictional name of a future period and the title of the last historical section of the novel - sees the globe divided into competing Water 
Conglomerates amid "the growing number of Displaced and Migratory Persons" (Siddique 2017, 254), leading to war and the desertion of warriors to the camp of the Regressives who hope for a simpler, more meaningful life, rather than remain in a society where travelling to the past is forbidden. Civilian populations and monks take to the road in $455 \mathrm{CE}$ in an effort to survive, both physically and spiritually, the onslaught of invading hordes: "A new people had arrived and they would murder and pillage for so long that no house would resemble a human dwelling and courtyards with calm images of Lord Buddha would look like slaughterhouses" (367), transforming the society forever. The Indian Mutiny of 1857 , and the cataclysmic social mutations which resulted from it, further illustrates the genuine historical consequences of politicallyregulated movement: "[T]he everyday terms of existence were far from illusory. They lived real lives. Increasingly uncertain lives. The old order was in its last throes and a new one stood by the side of the deathbed" (42). Whether at the level of an individual or of an entire society, "the social compulsion to move produces certain expulsions for all migrants" (Nail 2015, 2), exclusions of those who are seen as a threat to national identities and national economies because they fall outside the social order which seems to guarantee the disciplined bodies and minds which are the core of biopolitics as described by Foucault in The History of Sexuality:

[T]echniques of power present at every level of the social body and utilized by very diverse institutions [...] operated in the sphere of economic processes, their development, and the forces working to sustain them. They also acted as factors of segregation and social hierarchization, exerting their influence on the respective forces of both these movements, guaranteeing relations of domination and effects of hegemony. $(1990,141)$

3 When confronted with such existential threats and resistance, real or imagined, a sovereign often resorts to emergency measures, what Moira Fradinger, after Agamben and Schmitt, calls a "zone of exception," wherein the border between legal and illegal becomes blurred: "the law legally suspends itself, in order to preserve itself. A lawless space is thus legally bound: its violence is rationalized by the rhetoric of constituency survival and temporarily tolerated by the legal institutions" $(2010,17)$. Those who move are forced into this grey zone, both inside and outside the law. Snuffing Out the Moon traces four millennia of history, showing that the state of exception, rather than being "exceptional" or temporary, instead seems to be a permanent means to consolidate power, and that kinopolitics - or the politics of movement - is a technique of biopolitics and at the center of the state of exception as well.

Nail clearly states that "the figure of the migrant has always been the true motive force of social history" $(2015,7)$, and Siddique's novel lends itself to a kinopolitical approach to historical evolution. The novel, divided into five "books" each containing six historical periods, opens with a description of Mohenjodaro, 2084 BCE, a thriving, vibrant city along the mighty Indus river, traders coming and going, in short a model city which gives the impression of permanence, of always having been there. Yet if the primary basis of kinopolitics is the "analysis of social flows" (Nail 2015, 24), a secondary feature is the junction, or perceived stasis:

But this relative stasis is always secondary to the primacy of the social flows that compose it. A junction is not something other than a flow. It is the redirection of a flow back onto itself in a loop or fold. [...] The junction then acts like a filter or sieve that allows some flows to pass through or around the circle and other flows to be caught in the repeating fold of the circle. $(24,27)$ 
Seen from this perspective, it becomes clear that a city like Mohenjodaro at some point had to be created through movement, thus making Nail's claim unambiguous, that in fact, "settling down is the first kinopolitical event" (39). Given the vocabulary of social flows, it is perhaps not a coincidence that water imagery is abundant in Snuffing Out the Moon, and indeed Mohenjodaro is literally being drowned by heavy rains. In fact, its infrastructure has not been maintained due to the laxity of civic leaders since a fraudulent priestly caste has taken power. One young man, Prkaa, disgusted with the charlatans who have corrupted his city, is living in exile in the nearby forest; as an exile, or one who has been expelled, Prkaa is deprived of social status, "resulting in, or as a result of, [...] movement" (Nail 2015, 35). Whether Prkaa has chosen exile or has been expelled ultimately does not matter, since "migrants [...] are not free to determine the social conditions of their movement [...]. Expulsion is a fundamentally social and collective process because it is a loss of a socially determined status (even if only temporarily and to a small degree)" (Nail 2015, 36; original italics). Prkaa, though treated as a barbarian, as one who is outside the political order (Nail 2015, 15) by the city dwellers, is not naïve; he understands that the decline of the once-great city is due to the priests who have taken power, referred to as "illusion-makers" (Siddique 2017, 138).

5 In the novel, we are told that organized religions developed out of fear, becoming "a framework for tackling all the terrors of the unintelligible and the unknown" (Siddique 2017, 155), and evolved into a system of socio-political exploitation meant to control human beings, which is perfectly in line with Foucault's definition of biopolitics. We are equally reminded that an aforementioned junction is necessary to organized religion, a community of people living together and believing together (Nail 2015, 155):

Religion could no longer be left to mere men. It enfolded a possibility too immense to ignore any more, it encapsulated a tool too ingenious to neglect. [...] [I]t was only a matter of time before priestly persuasion evolved into exhortation and then into diktat. [The priests] required obeisance. They required submission. They even required a sacrifice no less than freshly shed blood. [...] The officiators of the new religion increasingly thought it fit to play a cardinal role not just in the domain of the spiritual but also in that of state, politics, commerce and even in the private lives of men and women. And who was to question them? (Siddique 2017, 156-57)

6 Even when their hoax is exposed and the voice of "god" has turned out to be a man hiding in a tree, this caste of sovereign priests, who have been sacrificing human beings, manages to remain in power. Their "technologies of the self" whereby "processes of subjectivization bring the individual to bind himself to his own identity and consciousness and, at the same time, to an external power" (Agamben 1998, 5; original italics), had been particularly efficient. If the creation of subjects is necessary to the sovereign, the state of exception is not a preexisting situation, but rather the means by which this caste of sovereign priests "creates and guarantees the situation that the law needs for its own validity" (17) within a society facing an apparent state of emergency, namely the aforementioned torrential rains and flooding.

7 Twenty-five hundred years later, in "The Land of the Buddha," the city of Mohenjodaro has all but disappeared under the sands of time. In the city of Takshasilla the monks have settled in the Jaulian monastery, the ruins of which will, in their turn, form the backdrop for the Deep History Center sixteen hundred years later. A senior scholar, Buddhamitra, is reproaching his brothers with their sedentary habits, as they remain in 
the sangharama when the tradition of the Buddha was to "go forth into the world" (Siddique 2017, 23). Buddhamitra adds: "the wheel of time takes yet another turn and the world around us is changing. [...] Surely, we need to be aware of what is happening beyond the walls of our monastery? Whether we like it or not, events transpiring outside can disrupt our quiet, reclusive lives within..." (23). The outside world is simply moving in, as it always does. Buddhamitra is not only worried about religious tradition; he has been having visions of invading hordes wiping out their current civilization (124), and taking to the road will be their only hope for survival, both for themselves and for the message of the Buddha they carry. And so the monks become exiles, although they take it in stride as the normal functioning of the wheel of time, or in the terms of kinopolitics, as the motive force of history: "Civilizational existence was nothing more than the tiresome sequence of horde after horde crossing deserts or descending from mountains, persecuting and uprooting those who had settled and flourished in the plains, only to be displaced in turn by the next series of marauders" (311).

8 Two forms of kinopolitical movement can be seen in this kind of situation, according to Nail: the invading hordes are nomad barbarians who "engage in one continuous raid following only the flows of blood and treasure - always searching for a home denied to them by political disenfranchisement" $(2015,138)$, while the monks become refugees, seeking asylum with their brothers in a distant monastery (135). The permanence of movement also becomes clear. If earlier we mentioned junctions as the points of perceived stasis, we now enter a system of circulation, or a "regulation of flows into an ordered network of junctions" (Nail 2015, 29), wherein the migrant (in whatever form, whether nomad, exile, refugee...) never really arrives at a destination (245; see endnote), especially given that invasions of one kind or another are a permanent feature, indeed a driving factor, of history.

9 Agamben links the phenomena of insurrection, invasion and resistance to the state of exception, highlighting the paradox that while the state of exception might seem to apply to abnormal, exceptional situations, within the concept of "'global civil war,' the state of exception tends increasingly to appear as the dominant paradigm of government in contemporary politics" $(2005,2)$. Siddique's novel develops a similar argument yet stretches much farther back in time to show that such techniques of government are nothing new, and will probably not change in future societies either, and certainly not during periods of imperial rule.

10 In $1620 \mathrm{CE}$, "The Land of the Mughal," we find Manmohan setting off on the Shah Rahe-Azam, the grand road "on which rode those who shaped their own destinies and indeed those of empires. Soon, he too would walk on it to escape a life of crushing tedium" (Siddique 2017, 25). As a young son to a large, poor farming family, Manmohan is a mere subject, a vagabond forgotten by history; the historical figure is Emperor Jahangir, The Seizer of the World, a genuine sovereign with effectively no limits to his power (Agamben 2005,8 ). Jahangir is a conqueror who has dramatically expanded his empire through what Nail refers to as a centripetal force:

In this way, territorial kinopower collectively brings the outside in. Thus, neither expansion nor expulsion is the effect of a single or central ruler, law, or power. Centripetal force does not emerge from the center; it emerges from a decentered periphery. It is the kinetic conditions for a social center. A single center can be created only by slowly accumulating from a heterogeneous periphery of individual farmers and even multiple territories. (2015, 43; original italics) 
Nail draws attention to the problem, saying that the migrant has been understood historically from the "perspective of states," in other words by those who have written the historical record, narratives in which the simple farmers and foot soldiers like Manmohan are ignored (2015, 4; original italics). But, of course, great empires also come and go despite their historical influence and impact.

11 Another major historical transition of empires highlighted by Snuffing Out the Moon is 1857 and the Indian Mutiny - or the First War of Indian Independence - the state of exception par excellence declared by the East India Company and the British Crown in response to Indian demands for full independence from British colonization. The British blame an itinerant maulvi, or teacher of Islamic law, Ahmadullah Shah, who "had travelled across northern Hindustan, inciting rebellion wherever he went" (Siddique 2017, 109), and they are concerned as well by the mystery of travelling chapattis across the country, which are suspected of being coded messages and which, disconcertingly, are delivered much more quickly than the post (104). When considering rebellions, Nail refers to the wave as the most appropriate form of motion to describe this kind of social movement:

A wave transports a qualitative change or social force of solidarity or collective disruption. [...] A social wave simply transports a disturbance through a social collective that unifies the collective without the source of the transport originating from any single point. [...] Social revolt travels rapidly in between the formal channels of power, through "word of mouth," print, association, and all manner of viral underground communications and secret meetings. Thus, a social wave is a distinctly mass or common phenomenon that requires a multitude of mutual pedetic motions in order to transmit a social disturbance among heterogeneous elements. (127; original italics)

Even though the Indians refuse to leave their homeland, their rebellion consists of movements nevertheless, the kind of Brownian, or pedetic movement described above. Rebellions, Nail reminds us, "are about seizing power directly without fleeing" (2015, 147). During this time of social upheaval, many travelled underground figuratively as well as literally, in elaborate systems of tunnels: "There was some comfort that all of them - whether stately or mean - almost always harboured those who were fleeing something and that too in great haste; an equalizing of humanity when it was underground, not unlike the egalitarian state in which all found themselves sooner or later, whether concealed in elaborate crypts or in dusty, untended graves" (Siddique 2017, 203). The British make prisoners of many of the Indian soldiers and civilians, all of whom are assumed to be guilty by association, people whose lives mean nothing, whose bare life status can be read on their bodies: "For they were men in limbo, moving about like wayward specters in the twilight. [...] They looked like debased men, and they walked like debased men, their eyes were those of debased men..." (289). Later in the novel, more prisoners are taken, but they will not remain prisoners for long: "The stragglers were to straggle no more. Such was the order. There was to be a blanket and permanent ban on all their movements. Now such a ban could only be truly implemented on lifeless bodies..." (393). These people are to be killed - but not sacrificed, since that would make martyrs of them - because they are stragglers, because they cannot move fast enough, because they cannot keep up.

In the context of a large-scale social revolt such as the Indian Mutiny, Nail describes the genesis of resistance as part of what he calls the "holy trinity of proletarianization (expulsion from property, urban labor and biological fecundity)" which then "gave 
birth to the social movement" allowing local struggles to evolve "into social and national struggles. [...] [T] he proletariat became the propertyless majority and their motion became a larger social movement" (2015, 159; original italics). Although the resistant Indian seems motionless in his/her refusal to move, in fact s/he continues to do so, moving "together in the picket-line, the public demonstration, the occupation...." (172). As we have seen, the self-proclaimed sovereign, in this case the East India Company and the Crown, reacts by repression, arrests with indefinite detention and killing, using the most basic logic to justify the state of exception, that of "necessity," which, Agamben reminds us, "has no law" $(2005,24)$. It ultimately destroys, through martial law and emergency powers, the very democracy (albeit limited) which the state of exception was supposed to defend, simply because there are no limitations on the exercise of power, no system of checks and balances (see Friedrich 1950, 584; also Agamben 2005, 8). While Indian independence was still ninety years in the future, the Mutiny was nevertheless a significant challenge to the sovereign, and indeed the East India Company found itself divested of that role, replaced entirely by the Crown in 1858, although Queen Victoria would not be officially proclaimed Empress of India until twenty years later. Another consequence of the Revolt would be a forced exodus of Muslims from Northern India, especially Delhi, which would later have an effect on Hindu-Muslim intercommunal relations up to and during Partition in 1947 and after, indeed right up to the present (Hashmi 2017).

Contemporary Lahore is the setting for the sections entitled "Wakeel," which focus on an old woman who is the victim of weak institutions and corruption. A gang of strongmen has occupied her house and refuses to pay rent, while the lawyer who is supposedly representing her case is simply taking her money while colluding with her tormenters. She is bound to, and yet abandoned by, the law (see Agamben 2005, 1). The law has become weak, and thus less effective - even powerless - due to the lack of violence in two ways, "the violence that posits law and the violence which preserves it" (Agamben 1998, 40). When the legal system becomes weak, like a watchdog which barks incessantly but never bites, the door is left open to those who understand that there are more efficient ways of governing than democracy and respect for the law.

This is the case as a senior army general decides to take power through a coup d'état, a state of exception which allows for a more efficient, albeit less humane, system of administration: "General Sahib had decided that no longer could the fate of the nation be left to the civvies [...]. General Sahib was a man of action and had little patience for the law. [...] General Sahib was a man of action and had even less patience for history" (Siddique 2017, 267-68; original italics). Although Al-Wakeel is one of Allah's ninety-nine names - The Trustee, The Disposer of Affairs, The Guardian - Wakeel can be defined linguistically as "the person who efficiently represents him [sic] or does what he is incapable of doing on his behalf" (Understand al-Qur'an Academy). While the old woman eventually finds an honest lawyer to represent her, perhaps more important to our discussion in terms of kinopolitics is the man who takes pity on the woman and steps in to help. The man, Billa, is an outlaw himself, fleeing for his life, yet before leaving his hideout he becomes the figure of Robin Hood, the sort of popular vagabond myth of the highwayman which Nail suggests, "supports peasant struggles, disguises himself as a beggar, hates the clergy, and fights the sheriff and his men" $(2015,150)$. In the current context of a military dictatorship, led by a sovereign General who has little patience for the law, the old woman has not completely lost her legal status yet requires someone from outside 
the law to defend her against the injustices of the state of exception and weak legal institutions (see Agamben 2005, 3).

Snuffing Out the Moon also takes us to the future, although not that far off, in 2084, to a world divided into competing Water Conglomerates. The Rohtas Fort Encampment, inspired by a real sixteenth-century fort near the city of Jhelum, is ultramodern and technologically advanced, kept secure by Airborne Monitoring and Patrol Scooters (AMPS) flown by skilled pilots. Every so often, one of the patrols manages to take a long-distance picture of those who are exiles, living outside the Fort, called Regressives by the city dwellers as they "seemed to belong to another age" (Siddique 2017, 60). One of the pilots, Naya, is curious about these people, and wonders why photos of them are so rare, and why "the Regressives were hardly spoken about. They were simply out there. Except when they needed to be checked" (61). The photos are on display in the Fort, until one day when Naya's close-up pictures of a family are also posted and cause quite a sensation, at least until they are censored a few minutes later - the man in the Regressive family is wearing the same kind of military-issue trousers that all AMPS pilots wear (63). Thus he is not simply an exile but a deserter, desertion being an extremely politically-charged form of movement or migration.

Nearly four years earlier, Combat Specialist Prashanto went missing after a seek and destroy mission, and was ultimately classified as Missing in Action (Siddique 2017, 84) after his AMPS inexplicably crashed in the jungle while pursuing some Regressives caught trying to divert water from the Conglomerate for their own use (79). Now that Naya's photos have unintentionally identified Prashanto, the authorities order an immediate recovery mission, classified as code red and confidential, with the addendum "Damnatio Memoriae" - no record is to be made of the operation (75; original italics), as a means of avoiding any martyrization: "Didn't one know how icons were born? If one neglectfully allowed a mythos to develop around someone or something, it became almost impossible to contain it at a later stage. 'The Burning Man,' 'The Tank Man,' 'The Falling Man,' 'The Passion of the Che'... various iconic images from some time earlier in the century flashed through [the Resident Reviewer's] fast-paced mind" (74-75). The Water Conglomerate has become a totalitarian society, controlling information and discouraging those who wish to consult historical archives, dismissed as "the countless fabrications fed to people over millennia in the name of a discipline that used to be called history" (62).

18 Prashanto, discussing why he left the Conglomerate to live with the Regressives, explains why he was unable to continue living in that environment, without a link to the past, without memory:

The loss of perspective has resulted from the forced break with the past - a horribly gory and death-dealing past by all accounts, but there is an absolute restriction on excavating it, examining it, learning from it - except for the select few. We are supposed to live solely in the present and in the future. So that the contagion of the past does not deprave us. The past is a curse that we are supposed to have escaped. It can never be allowed to catch up with and degenerate those who have, through their endless toil, finally regenerated. It is the necessary damnation of memory, some say. But how can one live without memory? (Siddique 2017, 230)

In terms of kinopolitics, this interdiction to consult the historical record in an effort to discover what "really" happened is not new. As Nail reminds us, those in power have always had power over the historical archive too, including the "countless fabrications" cited earlier: 
[M]igrants have created very different forms of social organization that can clearly be seen in the "minor history" of the raids, revolts, rebellions, and resistances of some of the most socially marginalized migrants. This is a challenging history to write because many of these social organizations produced no written documents, or if they did, they were systematically destroyed by those in power. It is not a natural fact that the history of migrants has become ahistorical, as Hegel argues - it is the violence of states that has rendered the migrant ahistorical. $(2015,4-5)$

In this violent society, religious faith has been banned in favor of "the cult of science and the order of progress" (Siddique 2017, 232), religion having become a humanistic foil to a technocratic, authoritarian regime rather than as a means of political domination. Instead, water scarcity has become a political tool, indeed a weapon of war (252) which has pushed many into exile, not simply those called Regressives:

In the wake of the Water Wars and after the so-called 'Transformation,' children, women and men had gone forth in caravans, small and large, clinging together for fear of persecution, and direly in need of water and security. After the stabilization of the extant global power balance among the Conglomerates, their places of exile became semi-permanent abodes. The reasons for their ouster were multifarious. Many had been turned away because they were deemed incapable of conforming; others had refused to conform and attune themselves to new post-religion lives. Yet others were born while their parents were in exile and knew of no other life [...] they all had something in common - their collective rejection by those who now controlled the water reserves of the world. (233)

This kind of expulsion is not surprising, Nail suggests: "The social conditions for the expansion of a growing political order (including warfare, colonialism, and massive public works) were precisely the expulsion of a population of barbarians who had to be depoliticized at the same time. This occurs again and again throughout history" (2015, 23). Such expulsion does not happen from a pre-established territory, in this case the Conglomerates' zones of influence and walled forts; rather territory is created via the expulsion of those who stand in the way: "The territory is not the condition for movement, but the inverse. [...] Before there is the territory, there is a process of territorialization" (42).

20 As we have said, historical research is strongly discouraged in this society; only near history studies, as they are called in the novel, are valued (Siddique 2017, 238). Alexander Al-Murtaza Afaqi was once a contemporary history specialist, renowned in his field, until he began to have doubts about what he was doing and about the ideological objectives his work served. So he is sent to the Deep History Studies Centre in Taxila, where in the shadow of the ruins of the Jaulian monastery, he is allowed to do his research, knowing that he is being monitored and that his work will at best be censored (236-40). Taxila is where Alexander Al-Murtaza Afaqi and people like him are confined when they are seen as "[n]ot yet volatile or seditious to qualify for surgical or chemical reorientation" (240). His work consists in comparing the role of water in the Indus Valley civilizations to that in his own time, millennia apart, while knowing his work will never be published (241).

21 Since her unwitting discovery of a deserter to the camp of the Regressives, Naya is also being subjected to questioning and scanning, treated as though she were a threat to the security of the Conglomerate, and is being considered for memory erasure, wondering aloud: "What kind of authority system played havoc with memory? What kind of society tolerated it without a word of explanation, without any disclosure? What did the authority have to hide and why?" (Siddique 2017, 246-47). During his interrogation 
with the Resident Reviewer, Alexander clearly shows that he understands the biopolitical justification for altering memory, defining it simply as "the age-old project of enforced normalization" (251). Both he and Naya will rebel. Alexander will leave microchips hidden inside several different statues, records of his writings that were not revealed to the Conglomerate, hoping that this historical archive, his personal, anticonformist archive, will travel to the future without being destroyed as subversive (425). In the last lines of the novel, Naya will bail out of her AMPS to join the Regressives below, as Prashanto had done four years earlier (427). While defined as deserters by the Conglomerate, and hence as criminals deserving the death penalty - " killed and yet not sacrificed," according to Agamben (1998, 8; original italics) - Nail suggests that what Prashanto, Naya and the Regressives have accomplished is yet another form of social movement, that of the commune which "proposes an alternative to the state" (167). The commune is, thus, a "wave invention of the proletariat" (Nail $2015,167)$, the wave provoking a qualitative change in society, as was mentioned above, that becomes a "permanent way of life" (139). As the Water Conglomerates seem to be in a constant state of conflict, both with each other and internally, security remains a top priority, thus justifying the state of exception and the resulting "generalization of the paradigm of security as the normal technique of government" (Agamben 2005, 14).

Snuffing Out the Moon, abundant with water imagery, is about migration through time and the social flows which drive history. At one point Prkaa seeks answers from his teacher: "I often wonder whether a civilization can always progress [...]. The more I think about all this, the more I am convinced that the affairs of men sometimes follow a course that becomes irreversible. It is like a tide which, once it rises, abates only when the natural time for it to abate arrives" (Siddique 2017, 334). Prkaa is pessimistic about the possibility for a small group of people to change the tide of history for the better, and his pessimism is understandable. Those social flows, or the movement of peoples, are almost never random but instead the result of political pressures: expulsions and expansions, invading armies, marauding hordes, imperial projects, exiles and desertions. If biopolitics is the creation of docile bodies for the purpose of controlling people and ensuring normalization (Foucault 1990, 141), kinopolitics must be considered as a means of accomplishing much the same thing, through enforced, regulated movement. As part of this constellation of governance, we see that the state of exception, rather than being the result of an exceptional situation is in fact the necessary element which defines the sovereign, allowing the sovereign to then reduce human beings to bare life, both inside and outside the law, permitting "both to protect life and to authorize a holocaust" (Agamben 1998, 3). While the state of exception is often discussed as a relatively recent historical phenomenon, especially focusing on totalitarian regimes during World War Two and after, Osama Siddique's Snuffing Out the Moon makes it clear that the exception has been the rule for thousands of years. Invoking necessity allows the sovereign to shape memories, to create collective amnesia, to rewrite history. Yet throughout Snuffing Out the Moon there are those who are nostalgic and curious, who seek to escape "the order of things" (Siddique 2017, 41), who try to see beyond appearances (15), those who doubt. Prkaa's teacher replies to his question: "This city may falter, fall and wither away. Or it may not. But those capable of building one such as this will not die out. We too will survive" (335). If movement is a tool of social control, it is also a means of resistance, of escape, of survival. 


\section{BIBLIOGRAPHY}

AGAMBEN, Giorgio. 1998. Homo Sacer: Sovereign Power and Bare Life. Translated by Daniel HellerRoazen. Stanford: Stanford University Press. Originally published as Homo sacer: Il potere sovrano $e$ la nuda vita. (Torino: Giulio Einaudi, 1995).

AGAMBEN, Giorgio. 2005. State of Exception. Translated by Kevin Attell. Chicago: University of Chicago Press. Originally published as Stato di eccezione. (Torino: Bollati Boringhieri, 2003).

FOUCAULT, Michel. 1990. The History of Sexuality: Volume 1, An Introduction. Translated by Robert Hurley. New York: Vintage Books / Random House. Originally published as Histoire de la sexualité (Paris: Gallimard, 1976).

FRADINGER, Moira. 2010. Binding Violence: Literary Visions of Political Origins. Stanford: Stanford University Press.

FRIEDRICH, Carl J. 1950. Constitutional Government and Democracy. 1941. Second edition. Boston: Ginn. HAMID, Mohsin. 2017. Exit West. London: Hamish Hamilton / Penguin Books.

HASHMI, Sohail. 2017. "1857-2017: The Mutiny which helped the British create Hindu-Muslim divide." National Herald. 29 July. https://www.nationalheraldindia.com/cafe/1857-2017-themutiny-which-helped-the-british-create-hindu-muslim-divide.

NAIL, Thomas. 2015. The Figure of the Migrant. Stanford: Stanford University Press.

NAIL, Thomas, and Zachary Thomas SETTLE. 2016. "Kinopolitics and the Figure of the Migrant: An Interview with Thomas Nail." Identity Issue. The Other Journal: An Intersection of Theology \& Culture, no. 27 (28 November). https://theotherjournal.com/2016/11/28/kinopolitics-figure-migrantinterview-thomas-nail/.

SIDDIQUE, Osama. 2017. Snuffing Out the Moon. Haryana, India: Hamish Hamilton/Penguin.

Understand al-Qur'an Academy. 2019. “And the answer is... Al-Wakeel!” 9 March. https:// understandquran.com/answer-al-wakeel.html.

\section{ABSTRACTS}

Osama Siddique's 2017 novel, Snuffing Out the Moon, is a migration through time. Shifting between six different historical eras in South Asia between 2084 BCE and 2084 CE, Siddique charts a politics of movement, or what Thomas Nail calls "kinopolitics." Snuffing Out the Moon traces four millennia of history, illustrating that the techniques of biopolitics and the related state of exception (or emergency measures) are often enforced through movement, and rather than being exceptional or temporary, seem to be a permanent means to consolidate power.

\section{INDEX}

Keywords: kinopolitics, biopolitics, state of exception, migration Indus Valley 


\section{AUTHOR}

\section{DAVID WATERMAN}

La Rochelle Université

David Waterman is a Professor at La Rochelle Université, where he is a member of the research team CRHIA (Center for Research in International and Atlantic History), Co-director of the doctoral program Euclide and Director of the Asia Pacific Institute. He is currently working on Pakistani history, culture and literature in English, and his most recent book-length publication is Where Worlds Collide: Pakistani Fiction in the New Millennium (Oxford University Press, 2015). 